\title{
Anti-inflammatory and anti-oxidant mechanisms of an MMP-8 inhibitor in lipoteichoic acid-stimulated rat primary astrocytes: involvement of NF-KB, Nrf2, and PPAR- $\gamma$ signaling pathways
}

Eun-Jung Lee ${ }^{1}$, Jin-Sun Park', Yu-Young Lee ${ }^{1}$, Do-Yeon Kim', Jihee Lee Kang ${ }^{2}$ and Hee-Sun Kim ${ }^{1 *}$ (D)

\begin{abstract}
Background: Recent evidence suggests that reactive astrocytes play an important role in neuroinflammation and neurodegenerative diseases. Thus, controlling astrocyte reactivity has been suggested as a promising strategy for treating neurodegenerative diseases. In the present study, we investigated whether a matrix metalloproteinase (MMP)-8 inhibitor, M8l, could control neuroinflammation in lipoteichoic acid (LTA)-stimulated rat primary astrocytes.

Methods: The effects of M8I on the expression of inducible nitric oxide synthase, cytokines, and MMPs were examined in LTA-stimulated rat primary astrocytes by ELISA, RT-PCR, and Western blot analysis. The effects of M8I on reactive oxygen species (ROS) generation and phase II antioxidant enzyme expression were examined by the DCF-DA assay, RT-PCR, and Western blot analysis. The detailed molecular mechanisms underlying the antiinflammatory and antioxidant effects of M8I were analyzed by the electrophoretic mobility shift assay, the reporter gene assay, Western blot, and RT-PCR analysis.
\end{abstract}

Results: Treatment with LTA, a major cell wall component of Gram-positive bacteria, led to astrocyte activation and induced the expression of inflammatory molecules such as iNOS, COX-2, and pro-inflammatory cytokines. In addition, LTA induced the expression of MMPs such as MMP-1, MMP-3, MMP-8, MMP-9, and MMP-13 in rat primary astrocytes. Based on previous reports showing that MMP-8 plays a role as a proinflammatory mediator in microglia, we investigated whether MMP-8 is also involved in inflammatory reactions of reactive astrocytes. We found that treatment of astrocytes with M8I significantly inhibited LTA-induced expression of iNOS, TNF- $\alpha, I L-1 \beta$, IL-6, and TLR2. In addition, M8I inhibited LTA-induced NF-KB, MAP kinase, and Akt activities, while it increased the antiinflammatory PPAR- $\gamma$ activities. Moreover, M8I showed antioxidant effects by suppressing ROS production in LTA- or $\mathrm{H}_{2} \mathrm{O}_{2}$-stimulated astrocytes. Interestingly, $\mathrm{M} 8 \mathrm{I}$ increased the expression of phase II antioxidant enzymes such as hemeoxygenase-1, NQO1, catalase, and MnSOD by modulating the Nrf2/ARE signaling pathway.

Conclusions: The data collectively suggest the therapeutic potential of an MMP-8 inhibitor in neuroinflammatory disorders that are associated with astrocyte reactivity.

Keywords: MMP-8 inhibitor, Astrocytes, Neuroinflammation, Anti-inflammatory, Antioxidant, Molecular mechanisms

\footnotetext{
* Correspondence: hskimp@ewha.ac.kr

${ }^{1}$ Department of Molecular Medicine, Tissue Injury Defense Research Center,

School of Medicine, Ewha Womans University, Mok-6-dong 911-1,

Yangchun-Ku, Seoul 158-710, South Korea

Full list of author information is available at the end of the article
}

(c) The Author(s). 2018 Open Access This article is distributed under the terms of the Creative Commons Attribution 4.0 International License (http://creativecommons.org/licenses/by/4.0/), which permits unrestricted use, distribution, and reproduction in any medium, provided you give appropriate credit to the original author(s) and the source, provide a link to the Creative Commons license, and indicate if changes were made. The Creative Commons Public Domain Dedication waiver (http://creativecommons.org/publicdomain/zero/1.0/) applies to the data made available in this article, unless otherwise stated. 


\section{Background}

Astrocytes are the most abundant cell type in the central nervous system (CNS) and play crucial roles in brain development, synaptic transmission, regulation of blood flow, ion homeostasis, and energy metabolism $[1,2]$. Insults to the CNS trigger the release of numerous factors that interact with astrocytes and trigger reactive gliosis, which is generally represented by hypertrophy and astrocyte proliferation. Recent studies have shown that there are two distinct types of reactive astrocytes, termed A1 and A2, which may be harmful or beneficial, respectively [3]. A1 astrocytes are rapidly induced by CNS injury and release neurotoxic factors such as glutamate, reactive oxygen species (ROS), and cytokines [4, 5]. In contrast, A2 astrocytes are induced by ischemia and express neurotrophic factors, promoting repair processes that protect against the effects of brain injury [3]. The reactive astrocytes seem to exist as a continuous spectrum of progressive changes with a mixed population. Recent studies reported that reactive astrocytes are found in vulnerable brain regions of animal models and patients with neurodegenerative diseases including Alzheimer's disease (AD), Parkinson's disease (PD), Huntington's disease (HD), amyotrophic lateral sclerosis (ALS), and multiple sclerosis (MS), suggesting the role of astrocytes in the pathogenesis of these diseases $[6,7]$.

Previous studies have reported that Gram-positive bacterial infections of the CNS occur in bacterial meningitis and trigger brain inflammatory responses $[8,9]$. In the CNS, astrocytes and microglia are considered targets of Gram-positive bacterial infection [10]. Lipoteichoic acid (LTA) is a major component of the Gram-positive bacterial cell wall that induces glial inflammatory activation, which is mediated through toll-like receptor 2 (TLR2) signaling [9, 11]. TLR2 is also involved in glial cell activation detected in non-infectious neurological disorders [12]. Several studies have demonstrated that TLR2 functions as a sentinel receptor to detect neuronal cell death and tissue damage in neurological conditions such as traumatic brain injury, intracerebral hemorrhage, and hippocampal excitotoxicity [13-15]. In addition, TLR2 on microglia functions as a receptor for fibrillary A $\beta$ peptide and oligomeric $\alpha$-synuclein and thereby modulates neuroinflammation during $\mathrm{AD}$ and PD $[16,17]$. Thus, TLR2 has been suggested as an efficient target to regulate unwanted inflammatory responses in neurological disorders.

Matrix metalloproteinases (MMPs) belong to zinc-containing endopeptidases that regulate cell-matrix composition and processing of bioactive molecules [18]. Under pathological conditions, aberrant expression of MMPs induces chronic inflammation and contributes to the progression of neurodegenerative diseases [19]. Several studies have demonstrated that MMP-8, also known as neutrophil collagenase, is involved in neuroinflammatory disorders such as bacterial meningitis, spinal cord injury, and multiple sclerosis [20-22]. Our group recently reported that MMP-8 plays a pivotal role in neuroinflammation via tumor necrosis factor (TNF)- $\alpha$ modulation in microglia [23]. We also demonstrated that MMP-8 is a novel pathogenic factor in focal cerebral ischemia [24]. Furthermore, MMP-8 mediates neuroinflammation in aged normal and LRRK2 G2019S Parkinson's disease model mice challenged with lipopolysaccharide (LPS) [25].

Although previous studies have demonstrated the role of MMP-8 in microglia [23-25], the role of MMP-8 in reactive astrocytes has not been clearly demonstrated. Therefore, in the present study, we examined the effect of the MMP-8 inhibitor in LTA-stimulated primary astrocytes and analyzed detailed molecular mechanisms.

\section{Methods}

\section{Reagents and antibodies}

All cell culture reagents and antibiotics were purchased from Gibco BRL (Grand Island, NY, USA). Purified lipoteichoic acid (LTA) from Staphylococcus aureus was obtained from InvivoGen (San Diego, CA, USA). The MMP-8 inhibitor, M8I, was purchased from Calbiochem (La Jolla, CA, USA). All reagents and enzymes for reverse transcription polymerase chain reaction (RT-PCR) and oligonucleotides for the electrophoretic mobility shift assay (EMSA) were purchased from Promega (Madison, WI, USA). Antibodies against phospho-/total forms of MAP kinases, $\beta$-actin, and MMP- 8 were supplied by Cell Signaling Technology (Danvers, MA, USA) and Abcam (Cambridge, UK). Antibodies against HO-1, NQO1, catalase, MnSOD, Nrf2, c-Jun, and lamin A were purchased from Santa Cruz Biotechnology (Santa Cruz, CA, USA). The antibody for phospho-p47 $7^{\text {phox }}$ (Ser370) was purchased from Assay Biotechnology Company Inc. (Sunnyvale, CA, USA). All other chemicals were obtained from Sigma-Aldrich, unless otherwise stated.

\section{Rat primary astrocyte cultures and cell viability test}

Primary astrocytes were cultured from the cerebral cortices of postnatal day 1 Sprague-Dawley rat pups as described previously [26]. In brief, after cortices were dissected from rat pups, cells were dissociated by pipetting through pores of different sizes and resuspended in minimum essential medium containing $10 \%$ fetal bovine serum, penicillin $(10 \mathrm{U} / \mathrm{ml})$, streptomycin $(10 \mu \mathrm{g} / \mathrm{ml}), 2$ $\mathrm{mM}$ glutamine, and $10 \mathrm{mM}$ 4-(2-hydroxyethyl)-1-piperazineethanesulfonic acid (HEPES). Cell suspensions were plated in poly-D-lysine $(1 \mu \mathrm{g} / \mathrm{ml})$-coated T75 flasks and incubated at $37^{\circ} \mathrm{C}$ under $5 \% \mathrm{CO}_{2}$. Seven days later, the culture flasks were shaken at $280 \mathrm{rpm}$ for $16 \mathrm{~h}$ to remove microglia and oligodendrocytes. The remaining astrocytes were trypsinized and seeded onto a culture plate and incubated for 6 days, with media being changed 
every 2 days. The purity of astrocyte cultures was $>95 \%$, as confirmed by Western blot and immunocytochemistry analyses using an antibody against glial fibrillary acidic protein. Cell viability was determined by 3-(4,5-dimethylthiazol-2-yl)-2,5-diphenyl tetrazolium bromide (MTT) reduction assay, as previously described [27].

\section{Measurement of cytokines and nitrite levels}

Primary astrocytes $\left(2 \times 10^{5}\right.$ cells per well in a 24-well plate) were pre-treated with M8I for $1 \mathrm{~h}$ and further stimulated with LTA $(10 \mu \mathrm{g} / \mathrm{ml})$ for $24 \mathrm{~h}$. The levels of TNF- $\alpha$ and IL- 6 released into the media were determined using ELISA kits according to the manufacturer's instructions (BD Biosciences, San Jose, CA, USA). Nitrite levels in the conditioned media were measured using Griess reagent (Promega). Absorbance at $550 \mathrm{~nm}$ was measured with a microplate reader (Molecular Devices, Sunnyvale, CA, USA).

\section{Determination of ROS generation}

A 2',7'-dichlorofluorescein diacetate (DCF-DA) assay was performed to observe the intracellular ROS level. Cells were plated in a 24-well plate and exposed to assigned doses of M8I and then stimulated with LTA $(10 \mu \mathrm{g} / \mathrm{ml})$ or $\mathrm{H}_{2} \mathrm{O}_{2}(500 \mu \mathrm{M})$. After $30 \mathrm{~min}$, the cells were stained with $50 \mu \mathrm{M} \mathrm{H}_{2}$ DCFDA and incubated at $37^{\circ} \mathrm{C}$ for $30 \mathrm{~min}$ in the dark. The fluorescent intensity of cells was detected at $485 \mathrm{~nm}$ excitation and $535 \mathrm{~nm}$ emission by fluorescence plate reader (Molecular Devices).

\section{Assay for MMP-8 activity}

Primary astrocytes $\left(2 \times 10^{5}\right.$ cells per well in a 24 -well plate) were treated with M8I prior to LTA stimulation for $1 \mathrm{~h}$, and the supernatants were collected to measure MMP-8 activity. The total MMP-8 activity was measured using the SensoLyte 520 MMP assay system (AnaSpec, San Jose, CA, USA) as described previously [28].

\section{Reverse-transcription polymerase chain reaction}

Total RNA $(1 \mu \mathrm{g})$ isolated from primary astrocytes was reverse transcribed, and synthesized cDNA was used as a template for PCR. Reverse-transcription polymerase chain reaction (RT-PCR) was performed on a T100 Thermal cycler (Biorad Laboratories, Hercules, CA, USA) with Go Taq polymerase (Promega). The gene-specific primers used are listed in Table 1. PCR products were visualized by ultraviolet illumination after electrophoresis. The amplified products were normalized using GAPDH as an internal control, and their values were calculated as fold change relative to control.

Table 1 Primers used in RT-PCR reactions

\begin{tabular}{|c|c|c|c|}
\hline Gene & Forward primer $\left(5^{\prime} \rightarrow 3^{\prime}\right)$ & Reverse primer $\left(5^{\prime} \rightarrow 3^{\prime}\right)$ & Size \\
\hline TNF-a & AAGTTCCCAAATGGGCTCCCT & TGAAGTGGCAAATCGGCTGAC & $306 \mathrm{bp}$ \\
\hline iNOS & GCAGAATGTGACCATCATGG & ACAACCTTGGTGTTGAAGGC & $426 \mathrm{bp}$ \\
\hline $\mid L-1 \beta$ & AAATGCCTCGTGCTGTCTGACC & TCCCGACCATTGCTGTTTCCT & $377 b p$ \\
\hline IL-6 & GAGTTCCGTTTCTACCTGGA & AGCCACTCCTTCTGTGACTC & $200 \mathrm{bp}$ \\
\hline $\operatorname{cox}-2$ & TCAGGAAGT TCCTTATTTCCTTTC & TGCGATGCTCTTCCGAGCTGTGCT & $479 \mathrm{bp}$ \\
\hline TLR2 & ATGAGGTTCTCCACCCAATA & AGACTCTGGAAGCAGGTGAC & $400 \mathrm{bp}$ \\
\hline MMP-1 & GCCATTACCAGTCTCCGAGGA & GGAATTTGTTGG CATGACTCTCAC & $467 \mathrm{bp}$ \\
\hline MMP-2 & GATCTGCAAGCAAGACATTG & AAGTGCTGGCAGAATAGACC & $242 \mathrm{bp}$ \\
\hline MMP-3 & GTACCAACCTATTCCTGGTTGC & CCAGAGAGTTAGATTTGGTGGG & $231 \mathrm{bp}$ \\
\hline MMP-8 & TACAACCTGTTTCTCGTGGCTGC & TCAACTGTTCTCAGCTGGGGATG & $317 \mathrm{bp}$ \\
\hline MMP-9 & AAGTTGAACTCAGCCTTTGAGG & GTCGAATTTCCAGATACGTTCC & $225 \mathrm{bp}$ \\
\hline MMP-13 & CGTAGTGATCAGAGCCAAGC & TCTGCCTITCCTGCAATTAGA & $225 \mathrm{bp}$ \\
\hline PPARY & CCGAAGAACCATCCGATT & CGGGAAGGACTTTATGTA & $271 \mathrm{bp}$ \\
\hline $\mathrm{HO}-1$ & ATACCCGCTACCTGGGTGAC & TGTCACCCTGTGCTTGACCT & $209 \mathrm{bp}$ \\
\hline NQO1 & ATCACCAGGTCTGCAGCTTC & GCCATGAAGGAGGCTGCTGT & $210 \mathrm{bp}$ \\
\hline Catalase & CCTGACATGGTCTGGGACTT & CAAGTTITTGATGCCCTGGT & $201 \mathrm{bp}$ \\
\hline MnSOD & GGCCAAGGGAGATGTTACAA & GAACCTTGGACTCCCACAGA & $216 \mathrm{bp}$ \\
\hline Nrf2 & AGCAGGACATGGATTTGATT & СTTCTCCTGTTCCTTCTGGA & $164 \mathrm{bp}$ \\
\hline c-Jun & AAGAACTCGGACCTTCTCAC & CTGGCTATGCAGTTCAGCTA & $207 \mathrm{bp}$ \\
\hline GAPDH & GTGCTGAGTATGTCGTGGAGTCT & ACAGTCTTCTGAGTGGCAGTGA & $292 b p$ \\
\hline
\end{tabular}




\section{Western blot analysis}

Equal amounts of protein were separated by SDS-PAGE and transferred to nitrocellulose membranes, and the membranes were blocked using 5\% skim milk in Tris-buffered saline with Tween-20 (TBST). After $1 \mathrm{~h}$, the membranes were incubated with primary antibodies against MMP-8 (1:1000, Abcam), the phospho- or total form of MAP kinases (1:1000, Cell Signaling), HO-1, NQO1, MnSOD, catalase, Nrf2, c-Jun, and lamin A (1:1000, Santa Cruz) at $4{ }^{\circ} \mathrm{C}$ overnight. Membranes were incubated with horseradish peroxidase-conjugated secondary antibodies (1:2000 dilution in TBST; Bio-Rad Laboratories), and an enhanced chemiluminescence detection kit was used for evaluations (Thermo Fisher Scientific, Waltham, MA).

\section{Transient transfection and luciferase assay}

Primary astrocytes $\left(2 \times 10^{5}\right.$ cells per well in a 12-well plate) were transfected with $1 \mu \mathrm{g}$ of plasmid DNA ([KB $]_{3}$-luc, ARE-luc, PPRE-luc) using Metafectene ${ }^{\circ}$ Pro transfection reagent (Biontex, Munich, Germany). After $36 \mathrm{~h}$ of transfection, cells were pretreated with M8I for $1 \mathrm{~h}$ and treated with LTA $(10 \mu \mathrm{g} / \mathrm{ml})$ for $6-16 \mathrm{~h}$. Then, cells were harvested and the luciferase assay was performed as previously described [26].

\section{Electrophoretic mobility shift assay}

Nuclear extracts from astrocytes were prepared as previously described [28]. Double-stranded DNA oligonucleotides containing the NF- $\mathrm{kB}$ or ARE consensus sequences (Promega) were end-labeled using T4 polynucleotide kinase (New England Biolabs, Beverly, MA) in the presence of $\left[\gamma_{-}^{-32} \mathrm{P}\right]$ ATP. Nuclear proteins $(5 \mu \mathrm{g})$ were incubated with a ${ }^{32} \mathrm{P}$-labeled probe on ice for $30 \mathrm{~min}$ and resolved on a 5\% acrylamide gel.

\section{Statistical analysis}

Unless otherwise stated, all experiments were performed with triplicate samples and repeated at least three times. Data are presented as mean \pm standard error of the mean (S.E.M.), and statistical comparisons among groups were performed using one-way ANOVA followed by Newman-Keuls post hoc tests or $t$ tests. Statistical significance was accepted for $p$ values $<0.05$.

\section{Results}

LTA induces the expression of proinflammatory cytokines, iNOS, COX-2, TLR2, and MMPs in rat primary astrocytes

To determine whether astrocytes are activated after LTA exposure, rat primary cultured astrocytes were treated with LTA $(0.1-10 \mu \mathrm{g} / \mathrm{ml})$ for $6-24 \mathrm{~h}$. We found that LTA significantly increased the production of $\mathrm{NO}$ and proinflammatory cytokines such as TNF- $\alpha$ and IL- 6 in a concentration-dependent manner (Fig. 1a). In addition,
LTA increased the mRNA expression of proinflammatory mediators, such as TNF- $\alpha$, IL- $1 \beta$, IL-6, iNOS, and COX-2 (Fig. 1b and Additional file 1: Figure S1). Interestingly, we found that LTA increased TLR2 mRNA expression, suggesting that LTA contributes to the regulation of its recognition receptor, TLR2. LTA also upregulated the mRNA expression of MMP-1, MMP-3, MMP-8, MMP-9, and MMP-13 without affecting MMP-2 (Fig. 1c and Additional file 1: Figure S1). These data indicate that LTA induces the expression of proinflammatory mediators by activating astrocytes.

\section{Inhibition of MMP-8 suppresses the production of} proinflammatory molecules in LTA-stimulated astrocytes Our previous studies demonstrated that MMP-8 modulates neuroinflammation in cultured microglia, septic mice, and cerebral ischemia [23, 24]. To determine whether MMP-8 also plays a role in LTA-mediated inflammatory responses in astrocytes, we examined the effect of M8I on the expression of various inflammatory molecules. First, we confirmed the protein expression of MMP-8 in LTA-stimulated astrocytesboth in cell lysates and conditioned media (Fig. 2a). LTA also increased the enzymatic activity of MMP-8, which was blocked by M8I (Fig. 2b). We found that treatment with M8I significantly inhibited the production of TNF- $\alpha$, IL-6, and NO in LTA-stimulated astrocytes (Fig. 2c). Moreover, M8I suppressed the mRNA expression of TNF- $\alpha$, iNOS, IL-1 $\beta$, IL- 6 , and TLR2 induced by LTA (Fig. 2d). M8I did not have any cytotoxicity in the concentrations used for at least $48 \mathrm{~h}$ (data not shown). The results imply the role of MMP- 8 as a proinflammatory mediator in activated astrocytes.

\section{M8I suppresses LTA-induced NF-KB activity with increasing PPAR- $\gamma$ activity}

To further investigate the anti-inflammatory mechanism of M8I, we examined the effect of M8I on NF- $k B$, a key transcription factor modulating proinflammatory gene expression in various immune cells [29]. We found that LTA increased the DNA binding activity of NF- $\mathrm{kB}$, which was inhibited by M8I (Fig. 3a). M8I also suppressed NF-kB-mediated transcription activity as shown by the reporter gene assay (Fig. 3b). Next, we examined the effect of M8I on PPAR- $\gamma$, a nuclear receptor that acts as an anti-inflammatory regulator in astrocytes and microglia [30, 31]. We found that the treatment of astrocytes with LTA significantly suppressed PPAR- $\gamma$ expression. The treatment with M8I, however, restored PPAR- $\gamma$ expression to near normal levels (Fig. 3c). Moreover, treatment with M8I without LTA also increased the expression of PPAR- $\gamma$. Next, to investigate whether M8I increases the transcriptional activity of PPAR- $\gamma$, a 

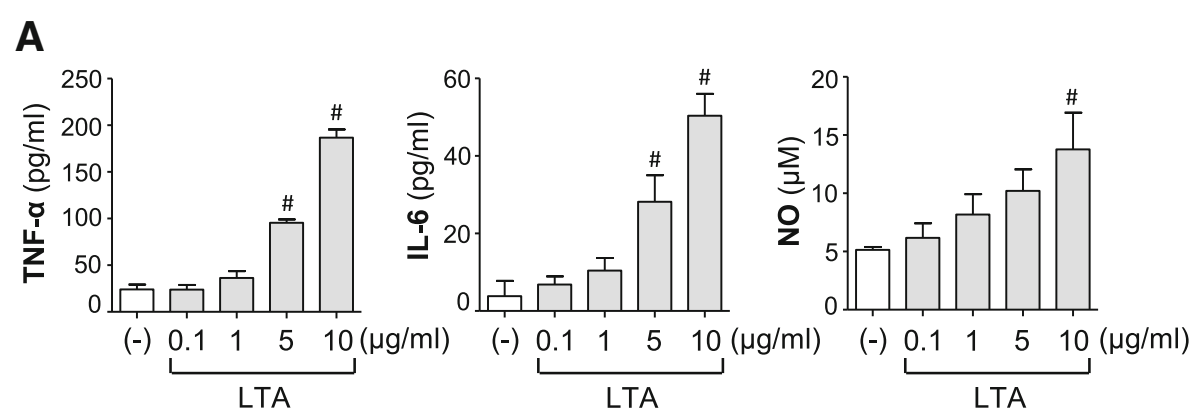

B

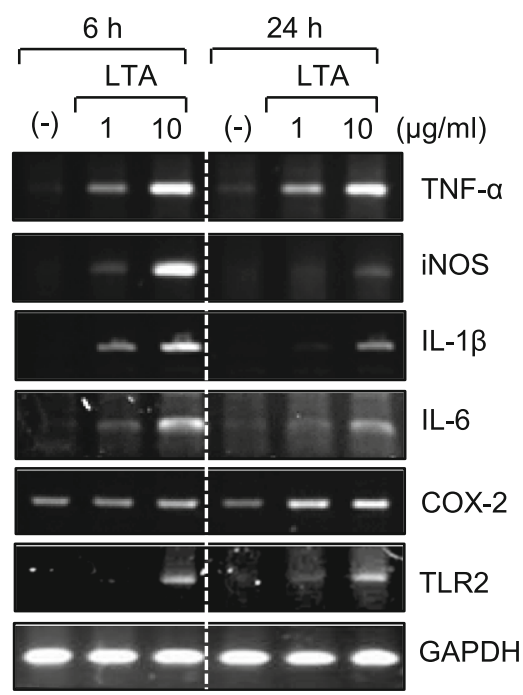

C

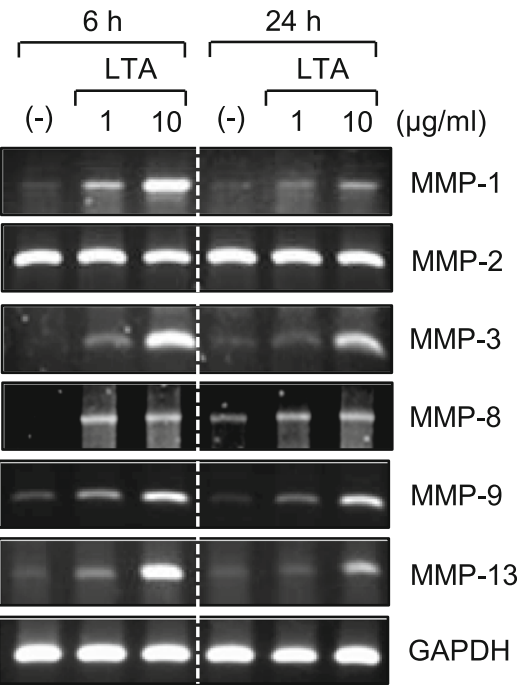

Fig. 1 LTA treatment increased the expressions of iNOS, COX-2, cytokines, TLR2, and MMPs in astrocytes. a Cells were treated with LTA (0.1, 1, 5, or $10 \mu \mathrm{g} / \mathrm{ml}$ ) for $24 \mathrm{~h}$. The amounts of TNF-a, IL-6, and NO were measured in the supernatants. The data are the mean \pm S.E.M. of three independent experiments. ${ }^{\#} P<0.05$, vs. control samples. b, c Cells were treated with LTA (1 or $\left.10 \mu \mathrm{g} / \mathrm{ml}\right)$ for $6 \mathrm{~h}$ or $24 \mathrm{~h}$. RT-PCR was performed to measure the mRNA expression of $\mathbf{b}$ iNOS, cytokines, COX-2, TLR-2, and $\mathbf{c}$ six types of MMPs. The data are representative of three independent experiments

cell-based reporter gene assay was performed. We found that M8I increased PPRE-luc activity in both the presence and absence of LTA (Fig. 3d).

\section{M8I inhibits LTA-induced phosphorylation of MAP kinases} and Akt

Next, we examined the effects of M8I on MAP kinases and Akt, which play an important role in proinflammatory gene expression by modulating transcription factors such as NF-KB [11]. We found that LTA induced the phosphorylation of three types of MAP kinase and Akt, and treatment with M8I markedly suppressed the phosphorylation of all these kinases in LTA-stimulated astrocytes (Fig. 4). These results suggest that MAP kinase and PI3K/Akt signaling pathways are involved in the anti-inflammatory action of M8I in LTA-stimulated astrocytes.
M8I shows antioxidant effects by inhibiting ROS production and increasing phase II antioxidant enzyme expression via Nrf2/ARE signaling axis

ROS are the byproducts of respiration and, at low levels, essential for biological function. However, excessive ROS give rise to inflammation-associated neurological disorders, including $\mathrm{AD}$ and $\mathrm{PD}[10,32]$. In the present study, we found that M8I inhibited intracellular ROS levels in LTA or $\mathrm{H}_{2} \mathrm{O}_{2}$-treated astrocytes, suggesting the antioxidant role of M8I in astrocytes (Fig. 5a, b). M8I also inhibited the phosphorylation of $\mathrm{p} 47^{\text {phox }}$ (Fig. 5c), a key component of NADPH oxidase complex responsible for ROS release in astrocytes [10]. To further investigate the antioxidant mechanism of M8I, we examined the effects of M8I on phase II antioxidant enzymes that are under the control of Nrf2/ARE signaling. We observed that M8I increased the expression of HO-1, 

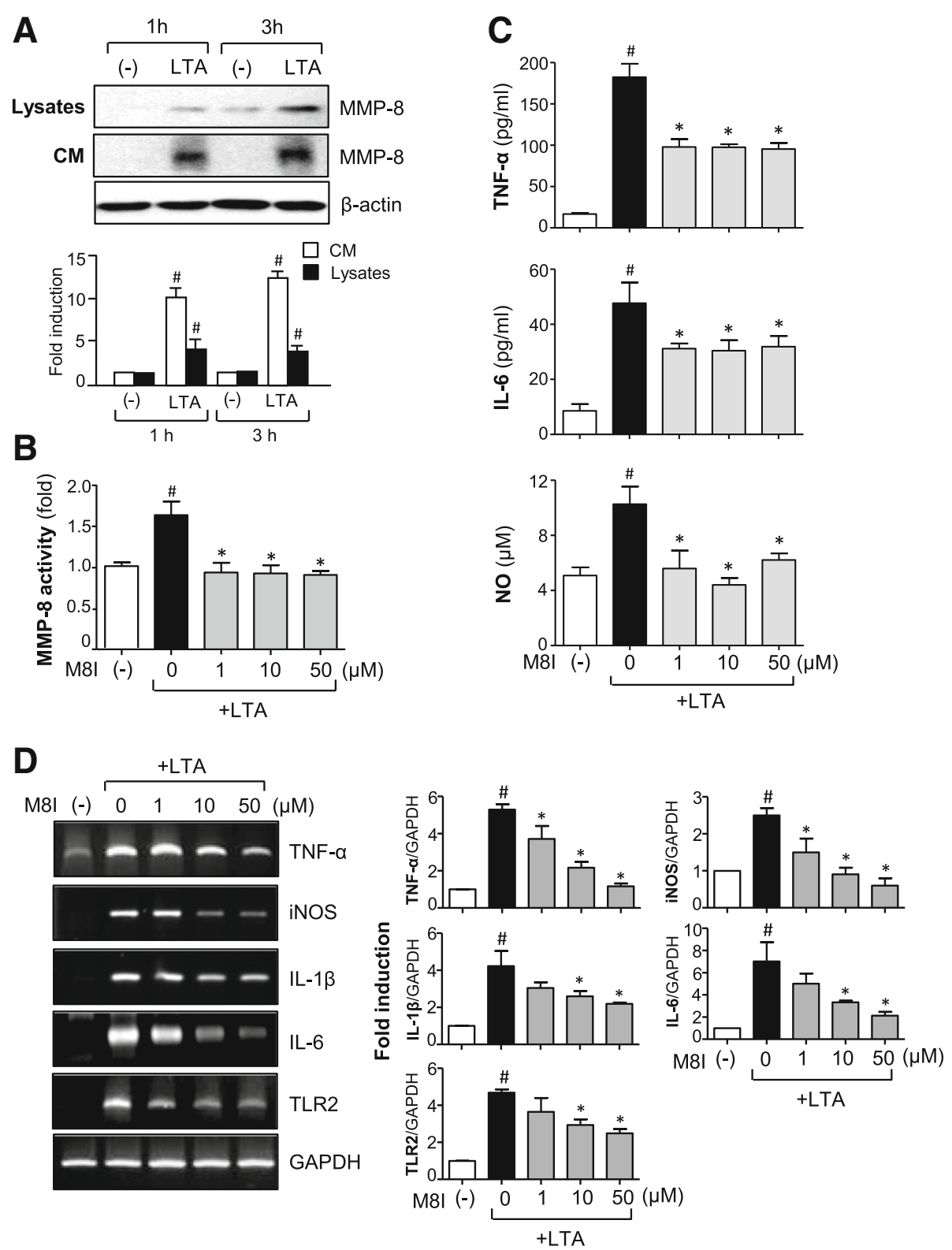

Fig. $2 \mathrm{M} 8 \mathrm{l}$ suppressed the expression of pro-inflammatory molecules in LTA-stimulated astrocytes. a Cells were treated with LTA (10 $\mu \mathrm{g} / \mathrm{ml})$ for 1 or $3 \mathrm{~h}$. MMP-8 protein expression was detected by Western blot in conditioned media (CM) and cell lysates. Representative blots (upper panel) and quantification data (lower panel) are shown. b MMP-8 activity assay data. Primary astrocytes were treated with M8l for $1 \mathrm{~h}$ before stimulation with LTA $(10 \mu \mathrm{g} / \mathrm{ml})$. One hour later, the supernatants were collected to measure MMP-8 activity using the SensoLyte ${ }^{\circledR} 520$ MMP-8 assay system. c The effect of M8I on TNF- $a$, IL-6, and NO production in cells treated with LTA for $24 \mathrm{~h}$. $\mathbf{d}$ The effect of M8I on the mRNA expression of iNOS, cytokines, and TLR2 was determined by RT-PCR analysis. The data are the mean \pm S.E.M. of three independent experiments. ${ }^{\#} P<0.05$, vs. control samples. ${ }^{*} P<0.05$, vs. LTA-treated samples

NQO1, catalase, and MnSOD at both mRNA and protein levels (Fig. $5 \mathrm{~d}-\mathrm{g}$ ). Next, we examined the effects of M8I on Nrf2/ARE signaling. EMSA data showed that M8I increased Nrf2 DNA binding activity in the absence or presence of LTA (Fig. 6a, b). The reporter gene assay employing ARE-luc also showed that M8I enhanced Nrf2-mediated transcriptional activities (Fig. 6c). The data suggest that upregulation of
Nrf2/ARE-mediated antioxidant enzyme expression may contribute to antioxidant effects of M8I in astrocytes.

\section{M8I increases the expression and nuclear translocation of} Nrf2 and c-Jun in astrocytes

We previously reported that $\mathrm{Nrf2}$ and c-Jun coordinately regulate the expression of phase II antioxidant enzyme 


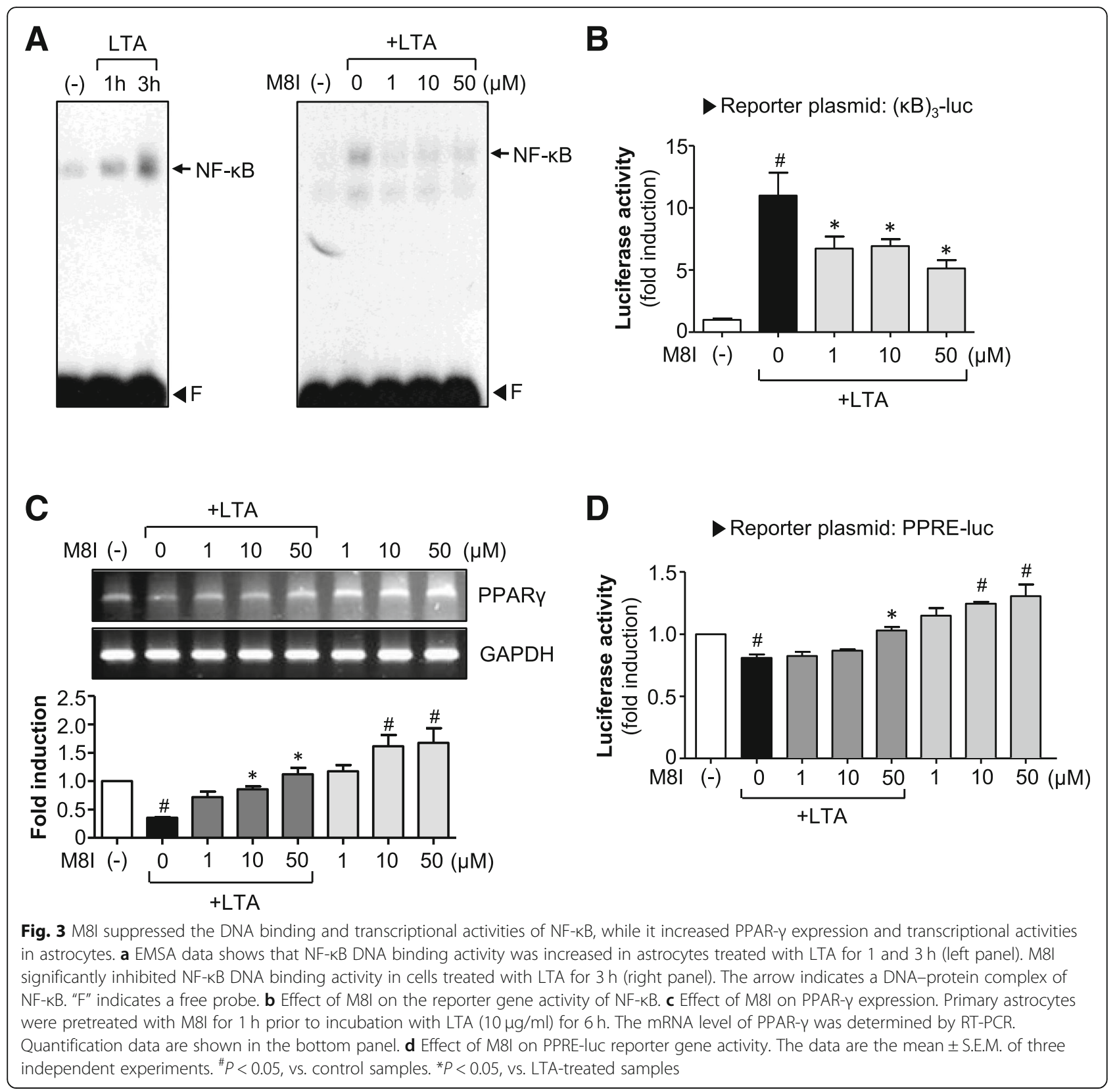

genes in rat primary astrocytes [33]. Therefore, in the present study, we examined the effect of M8I on Nrf2 and c-Jun expression. RT-PCR and Western blot analysis showed that M8I increased the expression of Nrf2 at both the mRNA and protein levels (Fig. 7a, b). Interestingly, M8I increased Nrf2 expression both in the absence and presence of LTA. Subsequently, nuclear translocation of Nrf2 was increased in M8I-treated cells (Fig. 7c). Unlike Nrf2, the mRNA expression of c-Jun was not significantly altered by M8I (Fig. 8a). However, M8I increased the protein expression and nuclear translocation of c-Jun (Fig. 8b, c). These data suggest that M8I modulates Nrf2 expression at the transcriptional level and c-Jun at the post-transcriptional level. Therefore, concomitant upregulation of Nrf2 and c-Jun by M8I may contribute to enhanced antioxidant enzyme expression in astrocytes.

\section{Discussion}

The present study demonstrated the anti-inflammatory and antioxidant effects of MMP-8 inhibitor in LTA-stimulated rat primary astrocytes. M8I inhibited various inflammatory molecules such as iNOS and cytokines such as TNF- $\alpha$, IL- $1 \beta$, and IL- 6 . Interestingly, M8I suppressed the expression of TLR2, the cell surface 
A

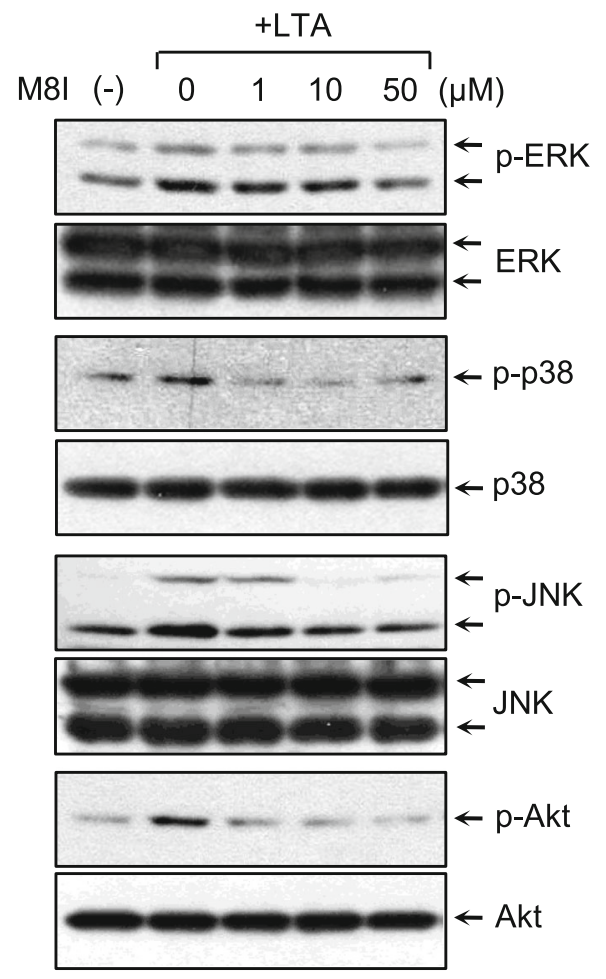

B

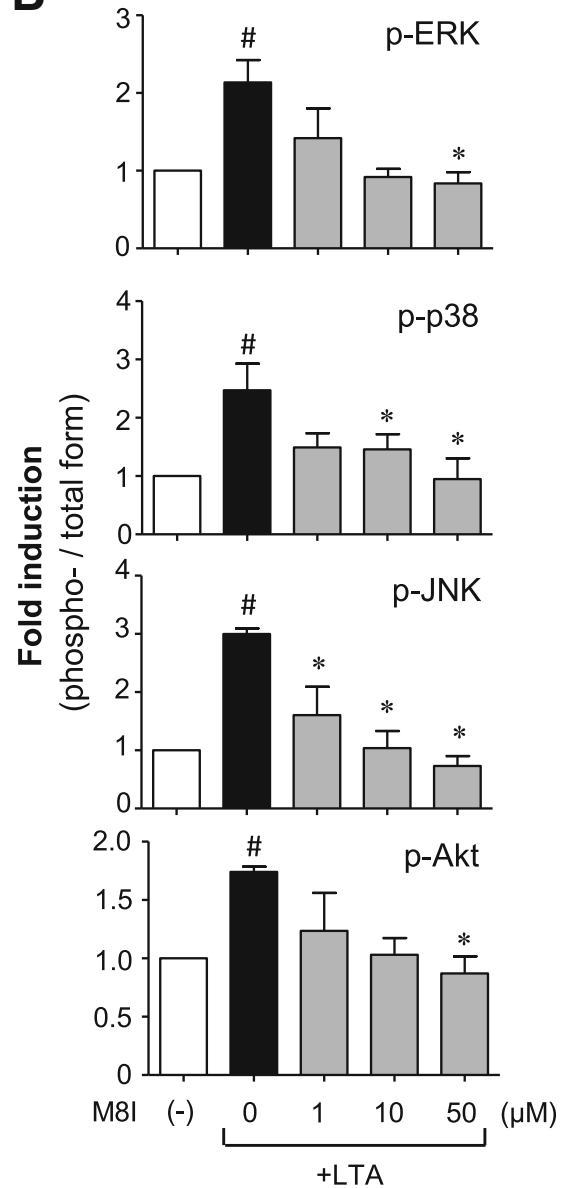

Fig. $4 \mathrm{M} 8 \mathrm{i}$ inhibited the phosphorylation of MAP kinases and Akt in LTA-stimulated astrocytes. a Western blot analysis for MAP kinases and Akt activities. Cell extracts were prepared from astrocytes treated with LTA $(10 \mu \mathrm{g} / \mathrm{ml})$ for $1 \mathrm{~h}$ in the presence or absence of M8l and then subjected to immunoblot analysis using antibodies against the phospho- or total forms of three types of MAPKs or Akt. The autoradiograms are representative of three independent experiments. $\mathbf{b}$ Quantification of Western blot data. Levels of the phosphorylated forms of MAP kinases and Akt were normalized with respect to the level of each total form and expressed as relative fold changes versus the control group. The data are the means \pm S.E.M. for three independent experiments. ${ }^{\#} P<0.05$, vs. control samples. ${ }^{*} P<0.05$, vs. LTA-treated samples

receptor of LTA, which may lead to attenuation of TLR2-mediated inflammatory signaling. Through mechanistic studies, we demonstrated that M8I exerts anti-inflammatory effects by blocking the MAPK, PI3K/ Akt, and NF- $k B$ and enhancing of PPAR- $\gamma$ activities. In addition, M8I showed antioxidant effects by upregulating phase II antioxidant enzyme expression via the Nrf2/ ARE signaling pathway. In particular, M8I upregulated the expression of Nrf2 and c-Jun, which coordinately regulate the expression of antioxidant genes. The data collectively suggest the therapeutic potential of M8I for neuroinflammatory disorders that are associated with reactive astrocytes as well as microglial activation.

Recent studies reported that the astrocyte reactivity is regulated by multiple signaling pathways including JAK/ STAT3, NF-кB, CN/NFAT, and MAP kinases [3, 4]. NF- $\mathrm{KB}$ activation in astrocytes plays an important role in chronic inflammation and the progression of neurodegenerative diseases. The JAK/STAT3 pathway appears to mediate the action of the A2 reactive astrocytes. However, the role of the JAK/STAT3 pathway in reactive astrocytes is rather controversial. Thus, modulation of these pathways has been suggested to be a potential therapeutic strategy for neurodegenerative diseases [3, 4]. In the present study, we found that M8I inhibited DNA binding and transcriptional activities of NF- $\mathrm{KB}$ in LTA-stimulated astrocytes. In addition, M8I inhibited three types of MAP kinases, which are also involved in astrocyte reactivity. Thus, the inhibition of NF- $\mathrm{kB}$ and MAP kinases appears to result in downregulation of inflammatory molecules such as iNOS and cytokines.

In this study, we found that M8I increased the expression of phase II antioxidant enzymes such as HO-1, NQO1, catalase, and MnSOD, which are governed by 


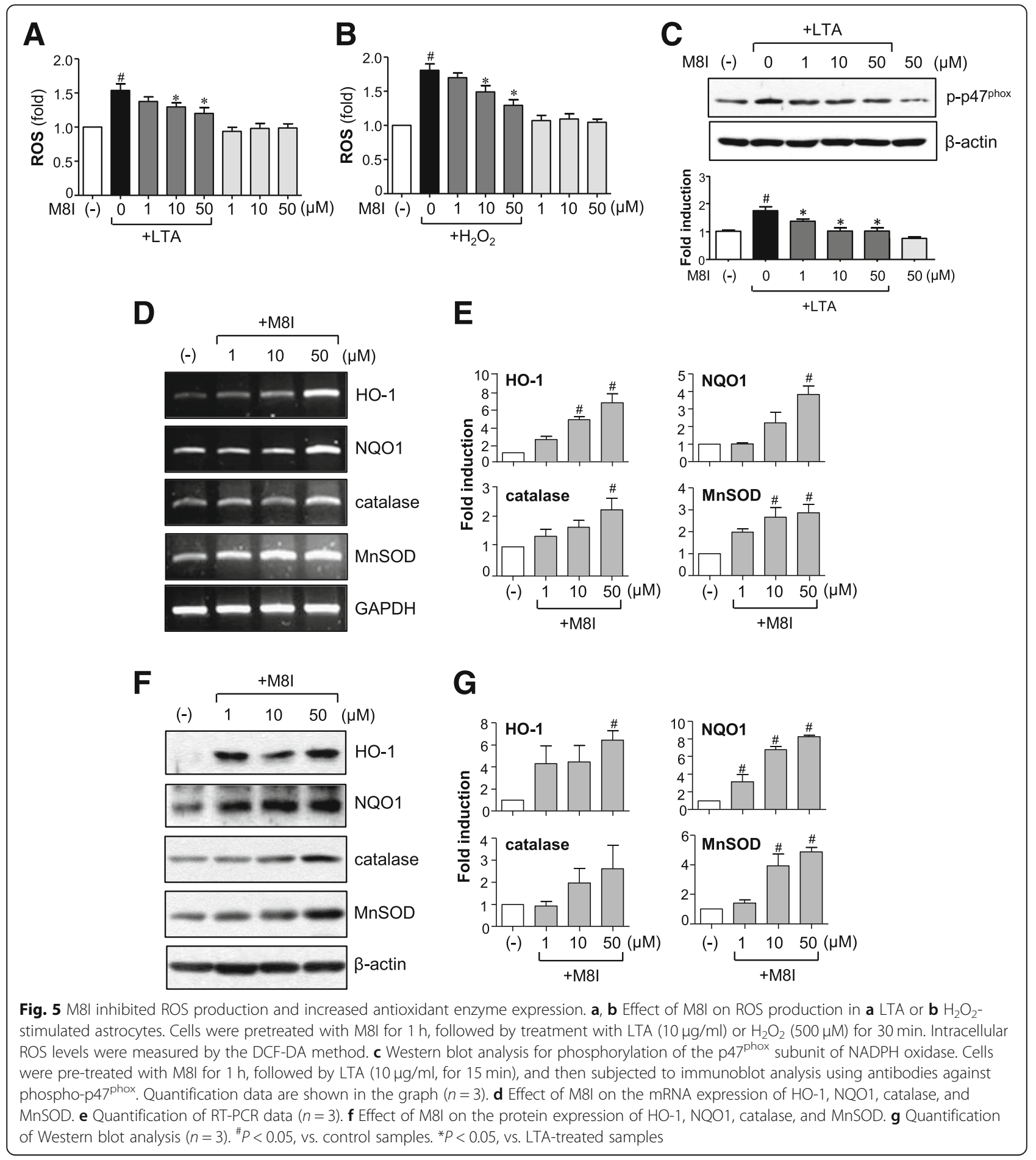

Nrf2/ARE signaling [34, 35]. The ARE-regulated genes are preferentially activated in astrocytes, which consequently have more efficient detoxification and antioxidant defenses than neurons [36]. Previous studies have reported that astrocyte-specific overexpression of $\mathrm{Nrf} 2$ protects against neurodegeneration in mouse models of
$\mathrm{AD}, \mathrm{PD}, \mathrm{ALS}, \mathrm{HD}$, and MS, suggesting that Nrf2 is a crucial therapeutic target for the treatment of many neurodegenerative diseases [37-40]. The results in the present study showed that M8I dramatically increased the expression and nuclear translocation of Nrf2 along with its counterpart c-Jun and subsequently increased 

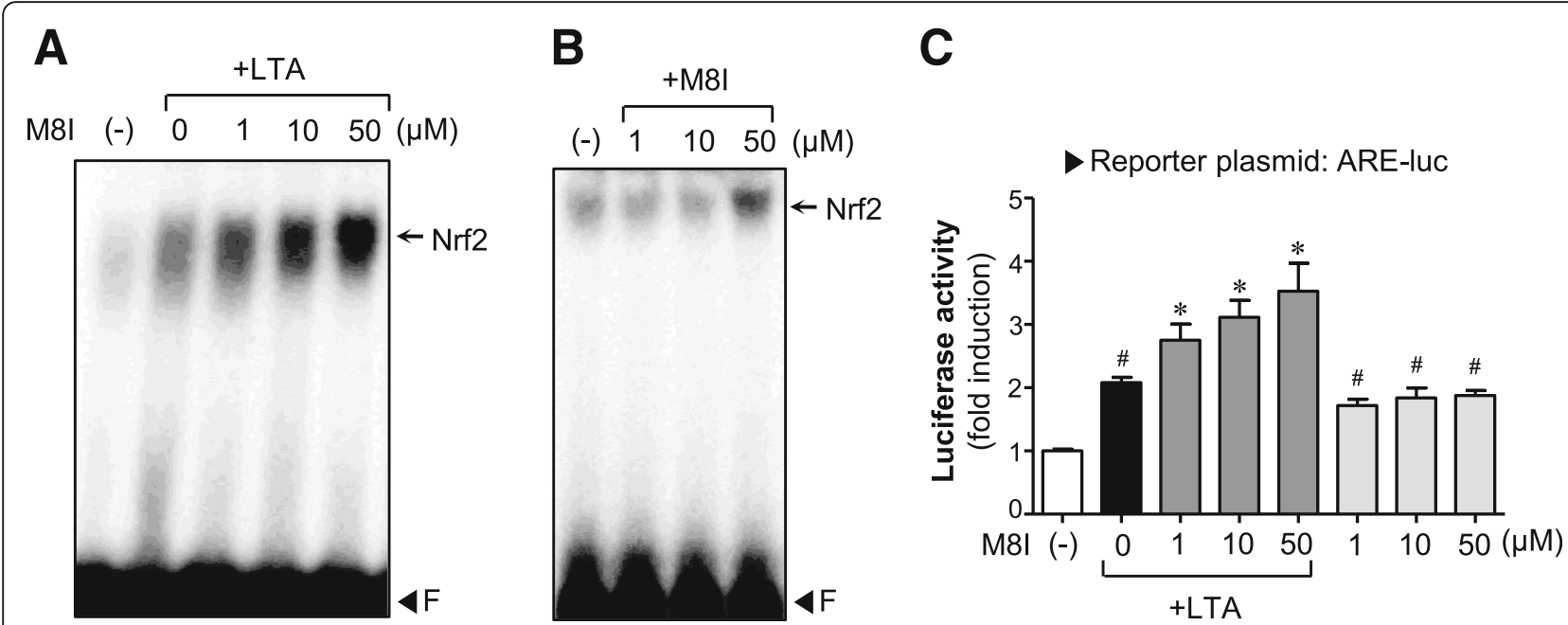

Fig. $6 \mathrm{M} 8 \mathrm{I}$ increased the DNA binding and transcriptional activities of Nrf2. $\mathbf{a}, \mathbf{b}$ EMSA for Nrf2 DNA binding activity. Nuclear extracts were prepared from astrocyte cells treated with M8I in the presence or absence of LTA (10 $\mu \mathrm{g} / \mathrm{ml})$ for $6 \mathrm{~h}$ and incubated with the probe (ARE). The arrow indicates a DNA-protein complex of Nrf2. c Effect of M8I on ARE-luc reporter gene activity. Astrocytes were transfected with the reporter plasmid (ARE-luc) and treated with M8I in the presence or absence of LTA for $6 \mathrm{~h}$, and luciferase assay was performed. The data are the means \pm S.E.M. for three independent experiments. ${ }^{\# P}<0.05$, vs. control samples. ${ }^{*} P<0.05$, vs. LTA-treated samples

the expression of antioxidant enzymes in astrocytes. Further studies are necessary to determine whether M8I-mediated upregulation of Nrf2 in astrocytes endows neuroprotection in diseased animal models.

The anti-inflammatory role of Nrf2 also has been reported by many papers [41]. In particular, $\mathrm{HO}-1$ is a well-known anti-inflammatory and antioxidant enzyme that is regulated through the Nrf2/ARE signaling pathway [42]. We have previously reported that the upregulation of HO-1 plays a key role in mediating the anti-inflammatory and antioxidant mechanism in LPS-stimulated microglia [43]. Carbon monoxide, one of the products of HO-1, has been reported to inhibit TLR signaling through suppression of NADPH oxidase-dependent ROS generation [44]. Therefore, the potentiation of Nrf2 and HO-1 by M8I may contribute to the anti-inflammatory and antioxidant effects of M8I in LTA-stimulated astrocytes.

Previous studies have reported that PPAR- $\gamma$ regulates the inflammatory responses mediated by astrocytes and microglia, protects neurons from damage, reduces oxidative stress, and improves mitochondrial function [30, 45]. PPAR- $\gamma$ has been reported to inhibit NF- $\mathrm{kB}$ activation and suppress the expression of proinflammatory molecules $[31,46]$. In addition, the interaction between PPAR- $\gamma$ and Nrf2 has been reported by many papers [47, 48]. Moreover, the effect of Nrf2 in ameliorating oxidative stress has been proposed to inhibit NF- $\mathrm{kB}$ [49]. Due to the interactions among PPAR- $\gamma, \mathrm{Nrf} 2$, and NF- $\mathrm{kB}$, it has been proposed that coactivation of Nrf2 and PPAR- $\gamma$ may improve the therapeutic outcome of neurological disorders [31]. In the present study, M8I increased
PPAR- $\gamma$ and Nrf2 with a decrement of NF- $\mathrm{KB}$ activities in astrocytes. Based on the previous studies, we speculate that PPAR- $\gamma$ may be involved in M8I-mediated anti-inflammatory and antioxidant effects in astrocytes by modulating NF- $\mathrm{kB}$ and Nrf2 signaling pathways.

In our previous study on the anti-inflammatory effect of an MMP-8 inhibitor in activated microglia, we reported that M8I specifically inhibited TNF- $\alpha$ processing and protease-activated receptor-1 activation, leading to blockage of inflammatory signaling [23, 50]. Moreover, M8I inhibited microglial activation and TNF- $\alpha$ expression in the brain of mice with systemic inflammation and cerebral ischemia, corroborating the findings through MMP-8 knockdown experiments [23, 24]. Although most of the data from experiments involving microglia and astrocytes indicated that the effects of M8I were largely mediated through MMP-8 inhibition, we cannot rule out the possibility of involvement of some nonspecific effects of M8I. Studies to clarify the MMP-8-dependent and MMP-8-independent effects of M8I in reactive astrocytes as well as microglia are necessary in future.

\section{Conclusions}

The present study reports, for the first time, the anti-inflammatory and antioxidant effects of an MMP-8 inhibitor in LTA-stimulated astrocytes. We demonstrated that M8I decreased proinflammatory molecules with an increment of antioxidant enzymes, in which NF- $\kappa B / N r f 2 / P P A R-\gamma$ signaling pathways are involved. Since reactive astrocytes play a crucial role in 


\section{A}
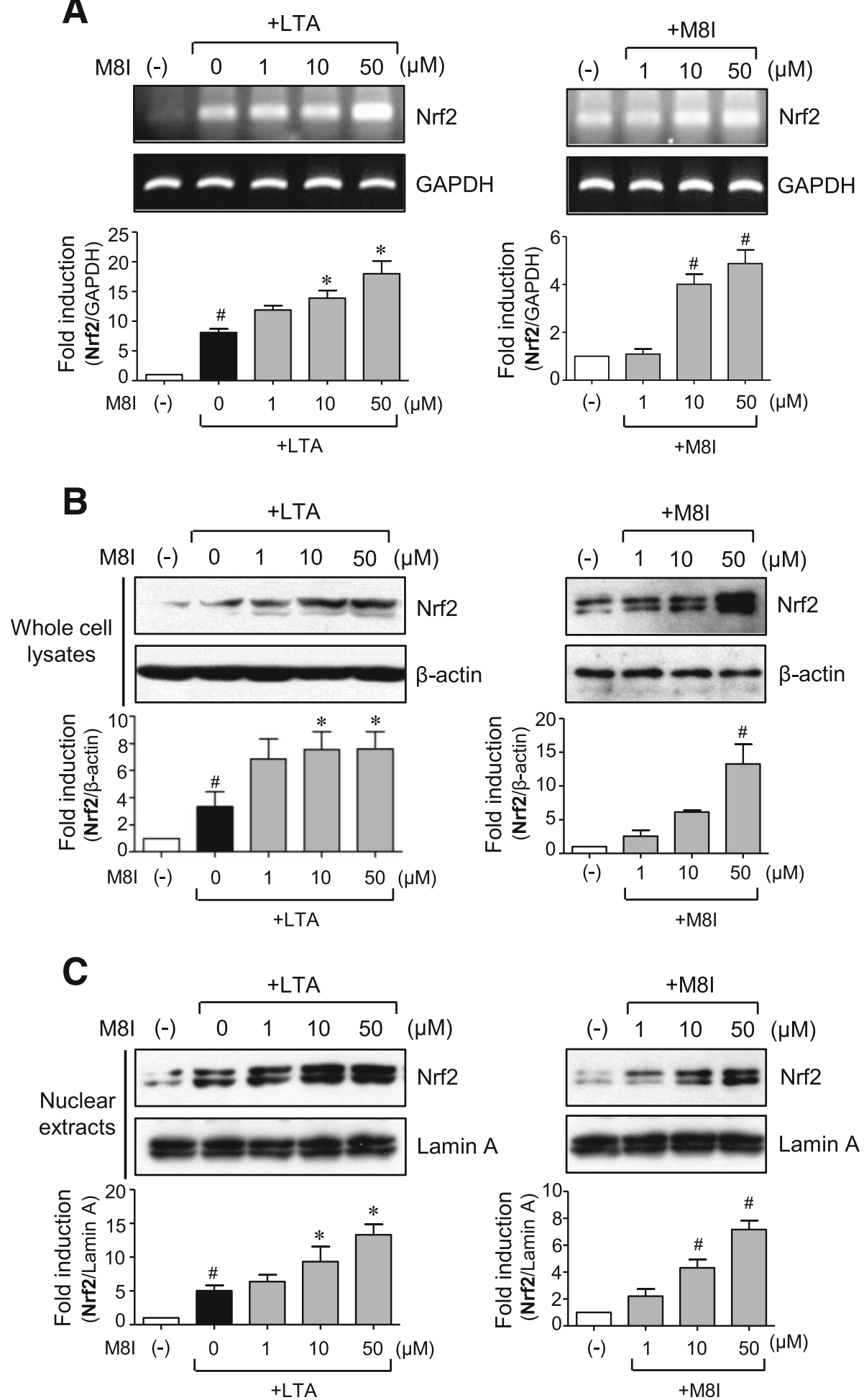

Fig. $7 \mathrm{M} 8 \mathrm{I}$ increased the expression and nuclear translocation of Nrf2 in astrocytes. Cells were treated with M8I in the presence or absence of LTA for $3 \mathrm{~h}$. a The effect of M8I on Nrf2 mRNA expression was determined by RT-PCR analysis. $\mathbf{b}$, c The protein levels of Nrf2 in $\mathbf{b}$ whole cell lysates and $\mathbf{c}$ nuclear extracts were determined by Western blot analysis. Quantification data are shown in the bottom panels. The data are the means \pm S.E.M. for three independent experiments. ${ }^{\#} P<0.05$, vs. control samples. ${ }^{*} P<0.05$, vs. LTA-treated samples 


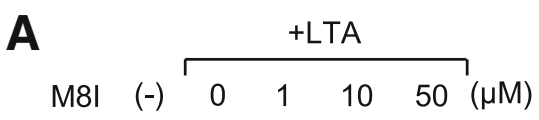
$( - ) \longdiv { 1 1 0 5 0 } ( \mu \mathrm { M } )$
$(-) \quad 1 \quad 10 \quad 50 \quad(\mu M)$
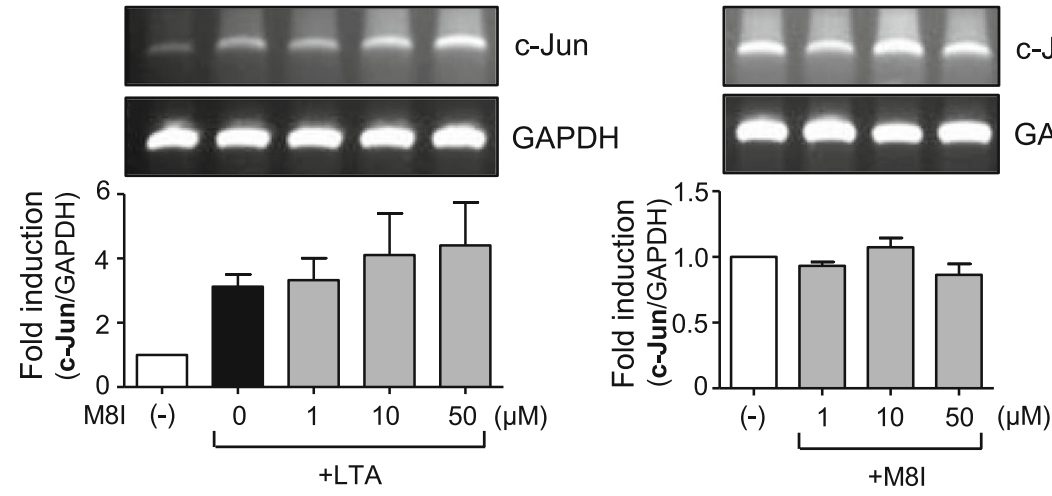

B
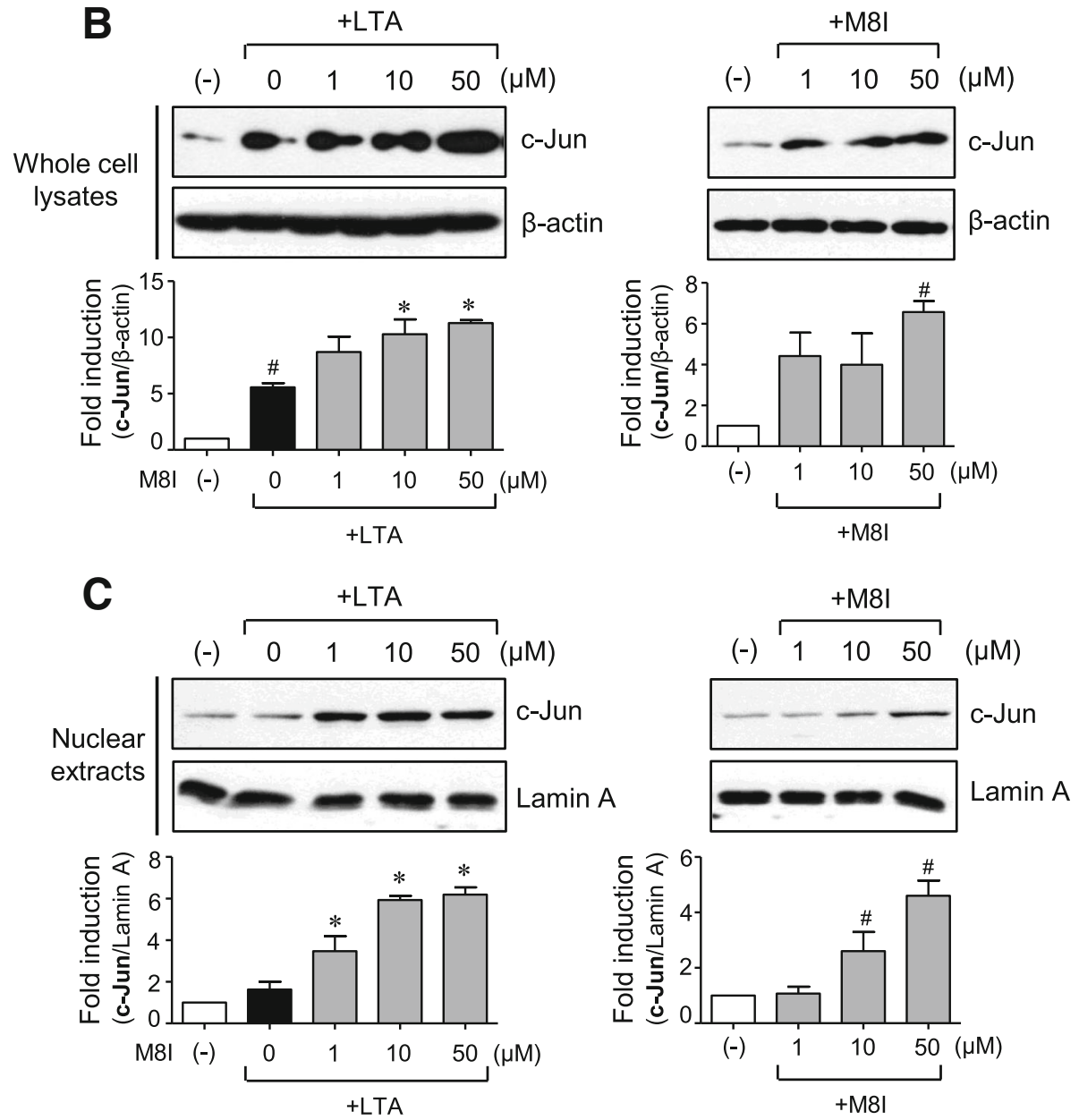

Fig. $8 \mathrm{M} 8 \mathrm{l}$ increased the expression and nuclear translocation of c-Jun in astrocytes. Cells were treated with M8I in the presence or absence of LTA for $3 \mathrm{~h}$. $\mathbf{a}$ The effect of M8I on c-Jun mRNA expression was determined by RT-PCR analysis. $\mathbf{b}, \mathbf{c}$ The protein levels of c-Jun in $\mathbf{b}$ whole cell lysates and $\mathbf{c}$ nuclear extracts were determined by Western blot analysis. Quantification data are shown in the bottom panels. The data are the means \pm S.E.M. for three independent experiments. ${ }^{\#} P<0.05$, vs. control samples. ${ }^{*} P<0.05$, vs. LTA-treated samples 
neuroinflammation and neuronal cell death, controlling astrocyte reactivity by M8I may provide therapeutic potential for neurodegenerative diseases.

\section{Additional file}

Additional file 1: Figure S1. Quantitative real-time PCR (RT-qPCR) data showing the expressions of iNOS, COX-2, cytokines, TLR2, and MMPs in LTA-simulated astrocytes. (PDF $438 \mathrm{~kb}$ )

\section{Abbreviations}

ARE: Antioxidant response element; EMSA: Electrophoretic mobility shift assay; ERK: Extracellular signal-regulated kinase; HO-1: Heme oxygenase-1; iNOS: Inducible nitric oxide synthase; JNK: c-Jun N-terminal kinase; LTA: Lipoteichoic acid; M8I: MMP-8 inhibitor; MAPK: Mitogen-activated protein kinase; MMP: Matrix metalloproteinase; MnSOD: Manganesedependent superoxide dismutase; NF-kB: Nuclear factor-kB; NQO1: NAD(P)H:quinone oxidoreductase 1; Nrf: Nuclear factor-E2-related factor; PPAR-ү: Peroxisome proliferator-activated receptor-ү; ROS: Reactive oxygen species

\section{Acknowledgements}

Not applicable

\section{Funding}

This research was supported by the National Research Foundation of Korea (NRF) grant funded by the Korea government (MSIT) (2010-0027945 and 2018R1A2B6003074).

\section{Availability of data and materials}

The datasets used and/or analyzed during the current study are available from the corresponding author on reasonable request.

\section{Authors' contributions}

The work presented here was carried out in collaboration between all authors. EL designed the study, performed the experiments, and wrote the manuscript. JP performed the experiments and analyzed the data. YL, DK, and JK helped in the preparation of the manuscript. HK supervised the design of the study, analyzed the data, and wrote the manuscript. All authors read and approved the final manuscript.

\section{Ethics approval and consent to participate}

Not applicable

\section{Consent for publication}

Not applicable

\section{Competing interests}

The authors declare that they have no competing interests.

\section{Publisher's Note}

Springer Nature remains neutral with regard to jurisdictional claims in published maps and institutional affiliations.

\section{Author details}

'Department of Molecular Medicine, Tissue Injury Defense Research Center, School of Medicine, Ewha Womans University, Mok-6-dong 911-1, Yangchun-Ku, Seoul 158-710, South Korea. ${ }^{2}$ Department of Physiology, Tissue Injury Defense Research Center, School of Medicine, Ewha Womans University, Seoul, South Korea.

Received: 28 July 2018 Accepted: 7 November 2018 Published online: 23 November 2018

\section{References}

1. Sofroniew MV, Vinters HV. Astrocytes: biology and pathology. Acta Neuropathol. 2010;119:7-35.
2. Singh A, Abraham WC. Astrocytes and synaptic plasticity in health and disease. Exp Brain Res. 2017;235:1645-55.

3. Liddelow SA, Barres BA. Reactive astrocytes: production, function, and therapeutic potential. Immunity. 2017:46:957-67.

4. Ben Haim L, Carrillo-de Sauvage MA, Ceyzériat K, Escartin C. Elusive roles for reactive astrocytes in neurodegenerative diseases. Front Cell Neurosci. 2015; 9:278.

5. Takano T, Kang J, Jaiswal JK, Simon SM, Lin JH, Yu Y, Li Y, Yang J, Dienel G, Zielke HR, Nedergaard M. Receptor-mediated glutamate release from volume sensitive channels in astrocytes. Proc Natl Acad Sci U S A. 2005;102: 16466-71.

6. Capani F, Quarracino C, Caccuri R, Sica RE. Astrocytes as the main players in primary degenerative disorders of the human central nervous system. Front Aging Neurosci. 2016;8:45

7. Liddelow SA, Guttenplan KA, Clarke LE, Bennett FC, Bohlen CJ, Schirmer L, Bennett ML, Münch AE, Chung WS, Peterson TC, Wilton DK, Frouin A, Napier BA, Panicker N, Kumar M, Buckwalter MS, Rowitch DH, Dawson VL, Dawson TM, Stevens B, Barres BA. Neurotoxic reactive astrocytes are induced by activated microglia. Nature. 2017;541:481-7.

8. Konat GW, Kielian T, Marriott I. The role of toll-like receptors in CNS response to microbial challenge. J Neurochem. 2006;99:1-12.

9. Neher JJ, Brown GC. Neurodegeneration in models of Gram-positive bacterial infections of the central nervous system. Biochem Soc Trans. 2007:35:1166-7

10. Hsieh HL, Lin CC, Shih RH, Hsiao LD, Yang CM. NADPH oxidasemediated redox signaling contributes to lipoteichoic acid-induced MMP-9 upregulation in brain astrocytes. J Neuroinflammation. 2012;9: 110.

11. Kang SS, Sim JR, Yun CH, Han SH. Lipoteichoic acids as a major virulence factor causing inflammatory responses via Toll-like receptor 2. Arch Pharm Res. 2016;39:1519-29.

12. Hayward JH, Lee SJ. A decade of research on TLR2 discovering its pivotal role in glial activation and neuroinflammation in neurodegenerative diseases. Exp Neurobiol. 2014;23(2):138-47.

13. Hong J, Cho IH, Kwak KI, Suh EC, Seo J, Min HJ, Choi SY, Kim CH, Park SH, Jo EK, Lee S, Lee KE, Lee SJ. Microglial Toll-like receptor 2 contributes to kainic acid-induced glial activation and hippocampal neuronal cell death. J Biol Chem. 2010:285:39447-57.

14. Lehnardt S, Lehmann S, Kaul D, Tschimmel K, Hoffmann O, Cho S, Krueger C, Nitsch R, Meisel A, Weber JR. Toll-like receptor 2 mediates CNS injury in focal cerebral ischemia. J Neuroimmunol. 2007;190:28-33.

15. Park C, Cho IH, Kim D, Jo EK, Choi SY, Oh SB, Park K, Kim JS, Lee SJ. Toll-like receptor 2 contributes to glial cell activation and heme oxygenase-1 expression in traumatic brain injury. Neurosci Lett. 2008;431:123-8.

16. Liu S, Liu Y, Hao W, Wolf L, Kiliaan AJ, Penke B, Rübe CE, Walter J, Heneka MT, Hartmann T, Menger MD, Fassbender K. TLR2 is a primary receptor for Alzheimer's amyloid beta peptide to trigger neuroinflammatory activation. J Immunol. 2012;188:1098-107

17. Kim C, Ho DH, Suk JE, You S, Michael S, Kang J, Joong Lee S, Masliah E, Hwang D, Lee HJ, Lee SJ. Neuron-released oligomeric alpha-synuclein is an endogenous agonist of TLR2 for paracrine activation of microglia. Nat Commun. 2013:4:1562

18. Mittal R, Patel AP, Debs LH, Nguyen D, Patel K, Grati M, Mittal J, Yan D, Chapagain P, Liu XZ. Intricate functions of matrix metalloproteinases in physiological and pathological conditions. J Cell Physiol. 2016;231:2599-621.

19. Brkic M, Balusu S, Libert C, Vandenbroucke RE. Friends or foes: matrix metalloproteinases and their multifaceted roles in neurodegenerative diseases. Mediat Inflamm. 2015;2015:620581.

20. Folgueras AR, Fueyo A, García-Suárez O, Cox J, Astudillo A, Tortorella P, Campestre C, Gutiérrez-Fernández A, Fanjul-Fernández M, Pennington CJ, Edwards DR, Overall CM, López-Otín C. Collagenase-2 deficiency or inhibition impairs experimental autoimmune encephalomyelitis in mice. J Biol Chem. 2018;283:9465-74.

21. Kumar H, Jo MJ, Choi H, Muttigi MS, Shon S, Kim BJ, Lee SH, Han IB. Matrix metalloproteinase-8 inhibition prevents disruption of blood-spinal cord barrier and attenuates inflammation in rat model of spinal cord injury. Mo Neurobiol. 2018:55:2577-90.

22. Schubert-Unkmeir A, Konrad C, Slanina H, Czapek F, Hebling S, Frosch M. Neisseria meningitidis induces brain microvascular endothelial cell detachment from the matrix and cleavage of occludin: a role for MMP-8. PLOS Pathog. 2010;6:e1000874. 
23. Lee EJ, Han JE, Woo MS, Shin JA, Park EM, Kang JL, Moon PG, Baek MC, Son WS, Ko YT, Choi JW, Kim HS. Matrix metalloproteinase-8 plays a pivotal role in neuroinflammation by modulating TNF-a activation. J Immunol. 2014;193:2384-93.

24. Han JE, Lee EJ, Moon E, Ryu JH, Choi JW, Kim HS. Matrix metalloproteinase-8 is a novel pathogenetic factor in focal cerebral ischemia. Mol Neurobiol. 2016;53: 231-9.

25. Kim J, Jeong YH, Lee EJ, Park JS, Seo H, Kim HS. Suppression of neuroinflammation by matrix metalloproteinase-8 inhibitor in aged normal and LRRK2 G2019S Parkinson's disease model mice challenged with lipopolysaccharide. Biochem Biophys Res Commun. 2017;493(2): 879-86.

26. Lee EJ, Choi MJ, Lee G, Gaire BP, Choi JW, Kim HS. Regulation of neuroinflammation by matrix metalloproteinase- 8 inhibitor derivatives in activated microglia and astrocytes. Oncotarget. 2017;8:78677-90.

27. Ryoo IG, Kim G, Choi BH, Lee SH, Kwak MK. Involvement of Nrf2 signaling in doxorubicin resistance of cancer stem cell-enriched colonospheres. Biomol Ther. 2016;24:482-8.

28. Lee EJ, Ko HM, Jeong YH, Park EM, Kim HS. $\beta$-Lapachone suppresses neuroinflammation by modulating the expression of cytokines and matrix metalloproteinases in activated microglia. J Neuroinflammation. 2015;12:133.

29. Choi SS, Lee HJ, Lim I, Satoh J, Kim SU. Human astrocytes: secretome profiles of cytokines and chemokines. PLoS One. 2014;9(4):e92325.

30. Iglesias J, Morales L, Barreto GE. Metabolic and inflammatory adaptation of reactive astrocytes: role of PPARs. Mol Neurobiol. 2017;54:2518-38.

31. Zhao XR, Gonzales N, Aronowski J. Pleiotropic role of PPARy in intracerebral hemorrhage: an intricate system involving Nrf2, RXR, and NF-KB. CNS Neurosci Ther. 2015;21:357-66.

32. Wang SM, Lim SW, Wang YH, Lin HY, Lai MD, Ko CY, Wang JM. Astrocytic CCAAT/Enhancer-binding protein delta contributes to reactive oxygen species formation in neuroinflammation. Redox Biol. 2018;16:104-12.

33. Park JS, Kim HS. Regulation of hemeoxygenase-1 gene expression by Nrf2 and c-Jun in tertiary butylhydroquinone-stimulated rat primary astrocytes. Biochem Biophys Res Commun. 2014;447:672-7.

34. Jaiswal AK. Nrf2 signaling in coordinated activation of antioxidant gene expression. Free Radic Biol Med. 2004;36:1199-207.

35. Lee JM, Li J, Johnson DA, Stein TD, Kraft AD, Calkins MJ, Jakel RJ, Johnson JA. Nrf2, a multi-organ protector? FASEB J. 2005;19:1061-6.

36. Vargas MR, Johnson JA. The Nrf2-ARE cytoprotective pathway in astrocytes. Expert Rev Mol Med. 2009;11:e17.

37. Chen PC, Vargas MR, Pani AK, Smeyne RJ, Johnson DA, Kan YW, Johnson JA. Nif2-mediated neuroprotection in the MPTP mouse model of Parkinson's disease: critical role for the astrocyte. Proc Natl Acad Sci U S A. 2009;106(8): 2933-8.

38. Gan L, Vargas MR, Johnson DA, Johnson JA. Astrocyte-specific overexpression of Nrf2 delays motor pathology and synuclein aggregation throughout the CNS in the alpha-synuclein mutant (A53T) mouse model. Neurosci. 2012;32(49):17775-87.

39. Johnson DA, Johnson JA. Nrf2 - a therapeutic target for the treatment of neurodegenerative diseases. Free Radic Biol Med. 2015;88:253-67.

40. Vargas MR, Johnson DA, Sirkis DW, Messing A, Johnson JA. Nrf2 activation in astrocytes protects against neurodegeneration in mouse models of familial amyotrophic lateral sclerosis. J Neurosci. 2008;28(50):13574-81.

41. Sandberg M, Patil J, D'Angelo B, Weber SG, Mallard C. NRF2-regulation in brain health and disease: implication of cerebral inflammation. Neuropharmacology. 2014;79:298-306.

42. Alam J, Cook JL. How many transcription factors does it take to turn on the heme oxygenase-1 gene? Am J Respir Cell Mol Biol. 2007;36:166-74.

43. Jung JS, Shin JA, Park EM, Lee JE, Kang YS, Min SW, Kim DH, Hyun JW, Shin CY, Kim HS. Anti-inflammatory mechanism of ginsenoside Rh1 in lipopolysaccharide-stimulated microglia: critical role of the protein kinase A pathway and hemeoxygenase-1 expression. J Neurochem. 2010;115(6): $1668-80$.

44. Nakahira K, Kim HP, Geng XH, Nakao A, Wang X, Murase N, Drain PF, Wang X, Sasidhar M, Nabel EG, Takahashi T, Lukacs NW, Ryter SW, Morita K, Choi AM. Carbon monoxide differentially inhibits TLR signaling pathways by regulating ROS-induced trafficking of TLRs to lipid rafts. J Exp Med. 2006; 203(10):2377-89

45. Zolezzi JM, Santosm MJ, Bastías-Candia S, Pinto C, Godoy JA, Inestrosa NC. PPARs in the central nervous system: roles in neurodegeneration and neuroinflammation. Biol Rev Camb Philos Soc. 2017;92:2046-69.
46. Ricote M, Li AC, Willson TM, Kelly CJ, Glass CK. The peroxisome proliferatoractivated receptor-gamma is a negative regulator of macrophage activation. Nature. 1998;391:79-82.

47. Cho HY, Gladwell W, Wang X, Chorley B, Bell D, Reddy SP, Kleeberger SR. Nrf2-regulated PPAR\{gamma\} expression is critical to protection against acute lung injury in mice. Am J Respir Crit Care Med. 2010;182:170-82.

48. Park EY, Cho IJ, Kim SG. Transactivation of the PPAR-responsive enhancer module in chemopreventive glutathione S-transferase gene by the peroxisome proliferator-activated receptor-gamma and retinoid $X$ receptor heterodimer. Cancer Res. 2004;64:3701-13.

49. Bowie A, O'Neill LA. Oxidative stress and nuclear factor-kappaB activation: a reassessment of the evidence in the light of recent discoveries. Biochem Pharmacol. 2000;59:13-23.

50. Lee EJ, Woo MS, Moon PG, Baek MC, Choi IY, Kim WK, Junn E, Kim HS. aSynuclein activates microglia by inducing the expressions of matrix metalloproteases and the subsequent activation of protease-activated receptor-1. J Immunol. 2010;185:615-23.

\section{Ready to submit your research? Choose BMC and benefit from:}

- fast, convenient online submission

- thorough peer review by experienced researchers in your field

- rapid publication on acceptance

- support for research data, including large and complex data types

- gold Open Access which fosters wider collaboration and increased citations

- maximum visibility for your research: over $100 \mathrm{M}$ website views per year

At BMC, research is always in progress.

Learn more biomedcentral.com/submissions 